\title{
$\left.\mathbf{C}^{-}\right\rceil \begin{aligned} & \text { CONGRESO } \\ & \text { INTERNACIONAL }\end{aligned}$
SOBRE \\ SOBRE \\ LF_O FOTOGRAFÍA
}

Congreso Internacional sobre Fotografía

UPV, 5 y 6 octubre 2017

Doi: http://dx.doi.org/10.4995/CIFo17.2017.7223

ISBN: 978-84-9048-604-7

\section{De la red a la mesa. Una metodología docente para pensar con imágenes.}

\section{Gema Pastor Andrés}

Universidad Rey Juan Carlos. gema.pastor@urjc.es

\begin{abstract}
The teaching methodology that is exposed below is being developed at the Master of Cultural Journalism and New Trends of the University Rey Juan Carlos (URJC) with the aim of learning how to think with images.

During the last 5 years we have developed, in the field of university teaching of the Faculty of Communication Sciences of the URJC, a workshop of creative photography that complemented the regulated teachings with the process of reflection and creation around the image, and in which the students had to develop a project. From the learnings of these years, together with the new forms of relationship with the contemporary image in which we are immersed, this new proposal arises.

And for this new workshop, we are proposing a working methodology with images that is based on the work of Aby Warburg and its Atlas Mnemosyne. This is an open process in which some images from internet are placed next to each other proposing a new montage that generates personal cartographies, beyond the logocentric culture structured in the word that is generated by the network, and through which it is able to propose a common and own culture structured by the image.
\end{abstract}

Keywords: Atlas, teaching, digital image, family and silent, imagination, table, play

\footnotetext{
Resumen

La metodología docente para pensar con imágenes que se expone a continuación se está desarrollando en el Máster de Periodismo Cultural y Nuevas Tendencias de la Universidad Rey Juan Carlos (URJC).

Durante los últimos 5 años hemos desarrollado en el ámbito de la enseñanza universitaria de la Facultad de Ciencias de la Comunicación de la URJC un taller de fotografía creativa que complementaba las enseñanzas regladas con la reflexión y creación en torno a la imagen y en el que el alumnado desarrollaba un proyecto. Del aprendizaje de estos años, y de las nuevas formas
} 
De la red a la mesa. Una metodología docente para pensar con imágenes. - From the net to the table. A teaching methodology to think with images.

de relación con la imagen contemporánea en las que nos vemos inmersos, surge esta nueva propuesta.

Para este nuevo taller se plantea la utilización de una metodología de trabajo con imágenes basada en la labor de Aby Warburg y su Atlas Mnemosyne. Un proceso abierto en el que las imágenes de internet se colocan unas junto a otras proponiendo un nuevo montaje que genera cartografías personales, más allá de la cultura logocéntrica estructurada en la palabra que genera la red, y a través de las que proponer una cultura común y propia estructurada por la imagen.

Palabras clave: atlas, docencia, imagen digital, familia y silencio, imaginación, mesa, juego 

images.

Todo este desarrollado ha abierto perspectivas y posibilidades nuevas de trabajo en torno a la imagen. Del aprendizaje de estos años y de las nuevas formas de relación con la imagen contemporánea en las que nos vemos inmersos, nos surgen 3 necesidades (objetivos) apremiantes del momento actual.

\section{Necesidades (objetivos)}

La primera necesidad que surge es la de desarrollar herramientas de pensamiento para poder abarcar la implosión cuantitativa de imágenes que nos rodea, sobre todo a través de las pantallas (según datos de 2016, 300 millones de imágenes se suben al día en Facebook, 1.600 en WhatsApp): ¿qué cuentan esas imágenes?, ¿cómo se distribuyen?, ¿qué necesidades cobijan?

La segunda se corresponde con propiciar procesos de trabajo abiertos y participativos donde sean las personas y no los contenedores de esas imágenes (redes sociales, medios de comunicación, empresas de telecomunicación...) las que propongan los nuevos cauces, más allá de su mercantilización, a través de los que estructurar y comunicar sus inquietudes: ¿quién decide cuáles son las imágenes más importantes?, ¿cuáles son los discursos autorizados y mayoritarios que se expresan a través de ellas?, ¿cuál es la superestructura conceptual implícita que las ordena?, ¿qué se nos impone?

La última proviene de la necesidad de visibilizar estructuras alternativas y generadoras de sentido a través de imágenes: ¿qué nos interesa?, ¿cómo nos gustaría contarnos?, ¿cuáles son nuestras inquietudes y las de los demás?

Para ello este taller plantea la utilización de una metodología de trabajo con imágenes basada en la labor de Aby Warburg y su Atlas Mnemosyne, un proceso abierto en el que las imágenes proponen discursos mediante técnicas de collage y montaje para crear cartografias personales, más allá de la cultura logocéntrica estructurada en la palabra que genera la red, y a través de la que proponer una cultura común y propia estructurada por la imagen. Para ello el taller desarrollará actividades de reflexión en torno a la imagen red, comprensión de la metodología del Atlas, desarrollo de un tema en profundidad y volcado de imágenes de la red en paneles en las mesas de trabajo; implementando una metodología innovadora que genera preguntas y respuestas a través del Atlas y que permite acciones para volver a repensar la imagen desde una posición propia; dando visibilidad a nuevas maneras de contarnos ¿qué necesidades, relaciones, relatos proponemos a partir de esos montajes?

\section{Taller de Imagen 2.0.}

Partiendo de estas necesidades el nuevo Taller de Imagen 2.0. amplía el foco sobre la imagen en general, una imagen que está hecha y que encontraremos en la red y que nos servirá con otras muchas para construir nuestros propios discursos sobre un tema a partir de una metodología concreta: el Atlas. Un montaje vivo e infinito en el que buscaremos los encuentros, las sinergias y los movimientos que surgen en la mesa (o la pared) en la que colocaremos esas imágenes y que irán construyendo nuevas formas de relación en torno a un tema, en este caso la familia y el silencio. 


\subsection{Estructura didáctica}

\subsubsection{Reflexiones en torno a la imagen red, pertinencia de la propuesta}

"La fotografía digital es consecuencia de una economía que privilegia la información como mercancía, los capitales opacos y las transacciones telemáticas invisibles. Tiene como material el lenguaje, los códigos y los algoritmos; comparte la sustancia del texto o del sonido y puede existir en sus mismas redes de difusión. Responde a un mundo acelerado, a la supremacía de la velocidad vertiginosa y a los requerimientos de la inmediatez y la globalidad". (Fontcuberta 2010)

Como resume excelentemente Fontcuberta en su libro La cámara de Pandora, la imagen digital que nos persigue allá dónde vamos en nuestros dispositivos móviles comparte con el texto y el sonido el lenguaje, los códigos y los algoritmos que tras indexarla permitirá sus movimientos a través de la red, porque ese es su objetivo como dispositivo comunicativo.

Nos preguntamos qué cuentan esas imágenes de la red, cómo se distribuyen, qué necesidades cobijan, quién decide cuáles son las imágenes más importantes, cuáles son los discursos autorizados y mayoritarios que se expresan a través de ellas, cuál es la superestructura conceptual implícita que las ordena, qué se nos impone...

Tras enviarnos una imagen, una amiga comprueba cómo ha desaparecido de su mail y en su lugar aparecen unas cuantas palabras que la describen con bastante acierto. Estupefacta, se da cuenta de que la imagen que había mandado ha pasado por filtros de identificación e indexado que permiten al contenedor de su cuenta de correo generar palabras relacionadas con la imagen.

La imagen había sido sustituida por la frase a la que seguían algunas palabras: La imagen puede contener: sábana, cama, almohada, edredón, cabecero, ropa de cama, relaciones sexuales, dormitorio, marco de la cama, novia, habitación, chinche, tamaño de la cama...

Podemos probarlo y comprobarlo en el programa online de google API VISION DE CLOUD que "extrae información valiosa a partir de las imágenes con nuestra potente API Vision de Cloud" (Google). El programa utiliza herramientas de inteligencia artificial y lectura de datos de la nube previamente etiquetados.

"clasifica imágenes rápidamente en miles de categorías (por ejemplo, "barco de vela", "león" o "torre Eiffel"), detecta objetos y caras individuales dentro de las imágenes, además de buscar y leer palabras impresas en ellas. Puedes crear metadatos en tu catálogo de imágenes, moderar el contenido ofensivo o habilitar nuevas situaciones de marketing mediante el análisis de sentimientos en imágenes. Tienes la posibilidad de analizar las imágenes cargadas en la solicitud o integrarlas en tu sistema de almacenamiento de imágenes de Google Cloud Storage" (Ibíd.).

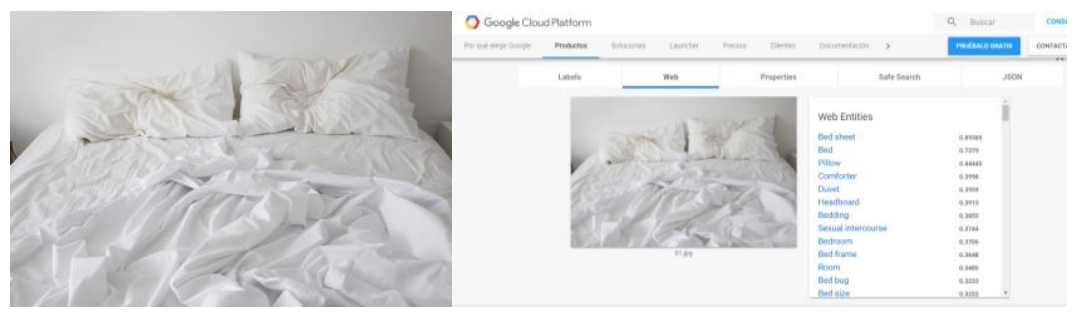



images.

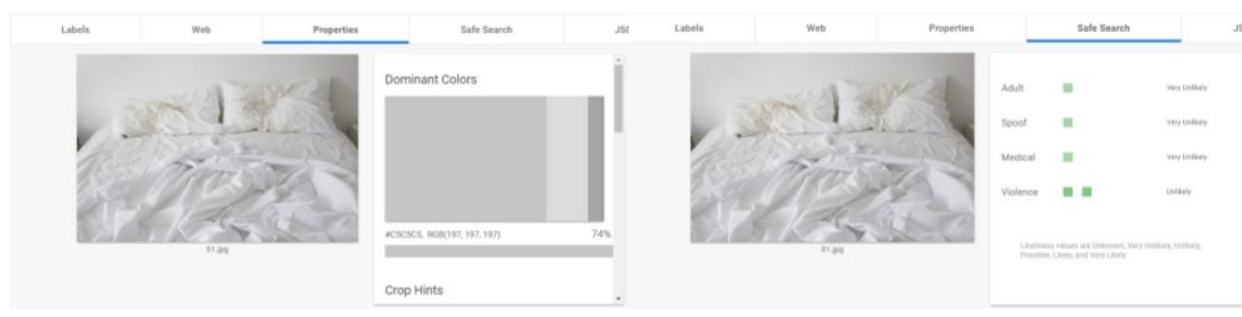

Fig. 2 Aplicación del programa API VISION DE CLOUD sobre una imagen, que da como resultado sus coincidencias con otras palabras en imágenes similares, su rango de colores dominantes, la calificación para adultos de la imagen...

Nosotros-as colgamos las imágenes, las etiquetamos, las indexamos, las buscamos... la sociabilidad digital en la que nos vemos inmersos ha diluido el ámbito privado y público en una superabundancia visual inabarcable.

Las imágenes se han vuelto escurridizas y difíciles de controlar, son inmateriales y transmisibles y están disponibles en cualquier momento en cualquier lugar en una pantalla (Fontcuberta 2016). La imagen creada para circular se lanza a la red para comunicar y comienza a ser indexada, o no, a aparecer, o no, en nuestras búsquedas.

“Cuanta más indexada esté más aparecerá, más visibilidad tendrá, pero en realidad si no se dispone de los medios necesarios internet es una tumba, la información puede desaparecer en la infinitud, para poder ser visible es necesario comprar todos los paquetes necesarios para ser visible. Internet es como un centro comercial, se repiten los cánones que están fuera de la red, los canales de distribución y poder. Solo algunos canales acumulan mucha visibilidad y ellos son los que distribuyen el tráfico, qué se ve y qué no se ve, qué va lo primero y qué va lo último". (Santamaria 2017)

Google explica que uno de sus objetivos primordiales es organizar toda la información que hay en el mundo, y la pregunta que podemos hacernos surge a partir de esta afirmación. Nosotros construirnos una identidad a través de sus estructuras, a partir de los datos que les damos, que les regalamos para seguir estando. ¿Quiénes somos y cómo nos construimos a través de esas imágenes?

Google atestigua la neutralidad del algoritmo PageRank con el que ordena los resultados de las búsquedas: una mezcla de Álgebra lineal, Teoría de Grafos y Probabilidad.

"PageRank es utilizado para medir la importancia de cualquier página web en Internet en función de los enlaces que dicha página recibe, aunque también se han utilizado ideas similares en otros contextos como el análisis de redes sociales o de redes de referencias bibliográficas (...) La formalización del algoritmo PageRank es bastante simple, dado un grafo $\mathrm{G}=(\mathrm{V}, \mathrm{E})$ donde $\mathrm{V}$ es un conjunto de vértices y $\mathrm{E}$ un conjunto de arcos dirigidos entre dos vértices, $\mathrm{E}(\mathrm{Vi})$ y $\mathrm{S}(\mathrm{Vi})$ que calculan, respectivamente, el número de arcos que entran o salen del vértice $\mathrm{Vi}$. A partir de estas dos operaciones básicas, se define la puntuación (o PageRank) de un determinado vértice" (Cruz, Troyano, Enríquez, Ortega 2016: 34).

En realidad el algoritmo constituye la razón de su éxito y "lo consigue más allá de cualquier expectativa: el 56 por ciento de las búsquedas que se realizaron a través de Internet, en el mundo entero, a principios del año 2005 , utilizaron ese motor." (Francois Fogel y Patiño 2005: 42). En el 2014, con los smartphones ya totalmente implantados, más del $80 \%$ de las búsquedas se realizaban a través de google, 10\% Yahoo y 5\% Bing; según varios estudios de consultoras internacionales (Merkle/RKG, comScore, StatCounter y Define Media) puesto que google no comparte esta información.

Estamos sometidos al bigdata y vivimos en una cultura visual dominada por la imagen. Necesitamos por lo tanto revisar nuestra situación, nuestro entorno y cómo nos movemos y construimos nuestra identidad en él. En esta cultura visual, dónde prevalece la estructura de la palabra, la fotografía puede constituirse en la esencia a través de la que mirarnos. 
Este papel convierte los productos de la cámara en materiales que transcienden lo meramente documental en tanto que discurso de verificación, para asumir en cambio un valor simbólico cuyo análisis resulta pertinente acometer al enjuiciar los regímenes de verdad que cada sociedad se autoasigna. (Fontcuberta 2010: 9)

\subsubsection{Atlas, una metodología}

Aby Warburg configuró al comienzo del siglo XX el Atlas Mnemosyne que recoge en paneles distintas imágenes agrupadas generando 'una iconología de los intervalos' (Warburg 2010). La propuesta de Warburg surge como una nueva forma de epistemología, una nueva forma de saber, que apuesta porque las imágenes agrupadas de esa otra manera son un recurso inagotable de relectura del mundo; en este caso de relectura de la historia del arte, del arte occidental relacionando todos los órdenes del saber, es decir de la historia de nuestras representaciones. Un pensamiento en movimiento que reconfigura la memoria de la cultura occidental.

La propuesta de este Taller de Imagen 2.0. quiere dejarse llevar por esta forma de pensar para generar también un atlas, no de la historia, sino de la contemporaneidad. Queremos a partir de 'la nueva ciencia', planteada por Warburg, proponer un ejercicio de relectura de las imágenes del mundo en la actualidad que nos permita intervenir en el imaginario que lo construye, no como algo cerrado y unidireccional que se presente como lo único posible, sino como el ejercicio resultante de un nuevo lenguaje no dominado todavía, una nueva forma de pensar que puede reconfigurar nuestras relaciones con las imágenes y con la idea de mundo. Nada pretencioso, pues esa será una de las infinitas posibilidades de agrupamiento y lectura del mundo a partir de imágenes, que aun así surgirá como verdad única y posible al aparecer como resultado de los intereses propios y arraigados en el alma del que lo genera. Un pensamiento que permita reconfigurar la identidad del presente.

Partiendo de conocimientos estructurados por la ortodoxia y la tradición ordenados en nuestras búsquedas de internet por algoritmos, por imágenes de la red propondremos nuevas relaciones posibles, un conocimiento nómada que surge en otras direcciones a las preestablecidas, dónde las impurezas y las singularidades pasan a formar parte de esa nueva estructura.

\begin{tabular}{|cc|}
\hline estructuradas & nuevas posibles \\
tradición & conocimiento nómada y otras direcciones \\
ortodoxias & impurezas \\
algoritmos & singularidades \\
\hline
\end{tabular}

La metodología del Atlas que Aby Warburg utilizó para estudiar la historia del arte, nos servirá aquí para explorar a través de tablas y láminas configuradas sobre una mesa esta forma visual del saber; para divagar sobre nuestras imágenes de hoy, para dejarnos llevar por el saber errático y nómada de esta nueva forma de conocimiento.

Para ello estudiaremos qué es un atlas, y qué no es; por qué se utilizan imágenes, qué tipo de imágenes se utilizan, cómo se relacionan con las otras, cómo se configuran en la mesa junto a las otras, qué estructuras, procedimientos y herramientas podremos utilizar para generar los intervalos que nos permitan leer el mundo, 'leer lo nunca escrito' (Warburg 2010) a partir del estudio que ha realizado George Didi-Huberman del trabajo de Aby Warburg en varias publicaciones (2011).

El Atlas es una herramienta que permite abrir lo posible y leer el mundo de las imágenes según sus relaciones íntimas y secretas, según las analogías y las correspondencias que mantienen entre ellas. Esta máquina de lectura, de lectura antes del lenguaje, antes del saber, es una infancia de la ciencia y del arte, pues permite leer antes del habla y del lenguaje. El atlas remueve las esencias del paradigma epistémico y del paradigma estético, 
De la red a la mesa. Una metodología docente para pensar con imágenes. - From the net to the table. A teaching methodology to think with images.

porque responde a una teoría del conocimiento expuesta al peligro de lo sensible y a una estética expuesta al peligro de la disparidad.

El atlas, como nuevo género del saber, apuesta por agrupar imágenes de una determinada manera, ofreciendo la posibilidad de relectura inagotable del mundo. Las imágenes empáticas acumulan distintos tipos de conocimiento y su agrupación en el atlas revelará sus relaciones transversales.

Para conseguirlo el atlas utiliza la imaginación, esa capacidad antropológica de relación entre órdenes alejados de realidad, como veremos en los primeros paneles del Atlas Mnemosyne (cielo, gesto, psique, humores orgánicos, entrañas, vísceras).

La imaginación es entonces la que dibuja correspondencias, analogías y renueva las estructuras, revela las relaciones inagotables, múltiples, infinitas, íntimas y secretas entre las imágenes empáticas, es el atlas que connota sentido a partir de montajes. La imaginación no es sensibilidad o fantasía, ni resumen o esquema, ni una estructura cerrada como la del diccionario que denota mensajes.

\begin{tabular}{c|c} 
La imaginación es & La imaginación no es \\
\hline relaciones íntimas y secretas & sensibilidad \\
también inagotables y múltiples, infinitas & fantasía \\
correspondencias & resumen \\
analogías & esquema \\
renovación & \\
\hline Atlas: connota montajes & Diccionario: denota mensajes
\end{tabular}

La imaginación se encuentra entonces entre dos órdenes del saber, lo sensible y lo inteligible, y requiere por lo tanto de la participación de elementos afectivos y elementos cognitivos para generar esas categorías inteligibles y esas representaciones mentales que revelen la organización de la sociedad.

La mesa se convoca como lugar de trabajo para el atlas, porque en ella las imágenes se encuentran, adquieren posiciones pasajeras, aparecen o no... hasta revelar relaciones íntimas y correspondencias. La mesa es el soporte de una labor con infinitas posibilidades, donde se puede corregir, modificar, comenzar de nuevo... en cualquier momento. El cuadro puede ser sublime, la mesa no, el cuadro es una obra única y cerrada, centrípeto en su planteamiento. La mesa propone bellezas y hallazgos en el plano horizontal en un movimiento centrífugo, en un movimiento indefinido.

El atlas no resume, no agota, las posibilidades de las imágenes sobre la superficie horizontal, pero no es un desorden loco, ni una ordenación cuerda, sino un análisis infinito que modifica el soporte, el espacio de aparición y disposición de las cosas dispares. Y al hacerlo sin reglas previas de disposición y relación, solo a partir de las múltiples relaciones íntimas y secretas que surgen entre las imágenes aparecerán los vínculos no evidentes. El conocimiento aparece entonces en su soporte, exposición, disposición y por supuesto contenido. La mesa es el lugar favorito del troceamiento del mundo, propenso a la aparición, el encuentro, que disocia y redistribuye, con síntomas propios y excepciones...

Para dejar brotar los intervalos en la mesa, y encontrar los vínculos no evidentes hay que sacudir lo familiar del pensamiento, trastornar las superficies ordenadas. Es el juego ideal del pensamiento y del arte que perturba la realidad, moralidad y economía, en un tiempo propio que afecta a lo que sucede y es afectado por ello. La vacilación e inquietud, el extrañamiento, el vértigo centrífugo, el absurdo, el desequilibrio, la incoherencia... 
(no en la extravagancia o lo incongruente) se produce en el montaje del atlas. El extrañamiento del lenguaje, la ruptura de la sintaxis y las palabras comunes pueden provocar risa, una risa un poco molesta, que burla la estabilidad de las relaciones.

Por eso nos interesa el atlas porque permite escapar del único punto de vista, desde el que perturbar la realidad, la moralidad y la economía de las estructuras mismas que eligen mediante algoritmos neutrales las imágenes para configurar el mundo.

Las imágenes pueden configurar nuevas formas de conocimiento e intercambio, nuevas formas de relación entre nosotros y entre nuestras representaciones; como lo demuestran innumerables trabajos en la red: las historias inventadas a partir de fotografías encontradas en rastrillos (http://palabraeimagen.com); las imágenes que punzan en nosotros en un álbum colectivo construido por los habitantes de Huesca (http://albumdehuesca.es/); la narración oral a partir de las imágenes (http://www.territorioarchivo.org) de Territorio Archivo de Chus Domínguez...

\subsubsection{El tema: la familia y el silencio}

El tema propuesto en esta primera convocatoria es La familia y el silencio (el error, la identidad, la infancia, la pose, la imagen de la mujer... surgen como ideas para posibles temas en los próximos años). El tema se ha propuesto por dos razones fundamentales.

La familia se ha elegido porque es la primera estructura social en la que nos construimos, también es la primera que acumula imágenes nuestras y de nuestra relación con los otros, y esas imágenes construyen nuestra identidad y configuran nuestra relación con la realidad desde que llegamos a este mundo.

El silencio se ha elegido porque las imágenes fijas, las fotografías, siempre son silenciosas e inmóviles, rescatan un momento congelado que podemos observar en cada detalle el tiempo que estimemos oportuno.

El binomio invoca a la búsqueda de nuestras propias narrativas alternativas y a la búsqueda desde nuestra-s propia-s imagen-es. Para profundizar en el tema se revisa el trabajo de algunos artistas que han retratado su entorno familiar. Las narrativas alternativas de los artistas aportan puntos de vista distintos a los canónicos sobre el tema como podemos ver en una rápida búsqueda en google.
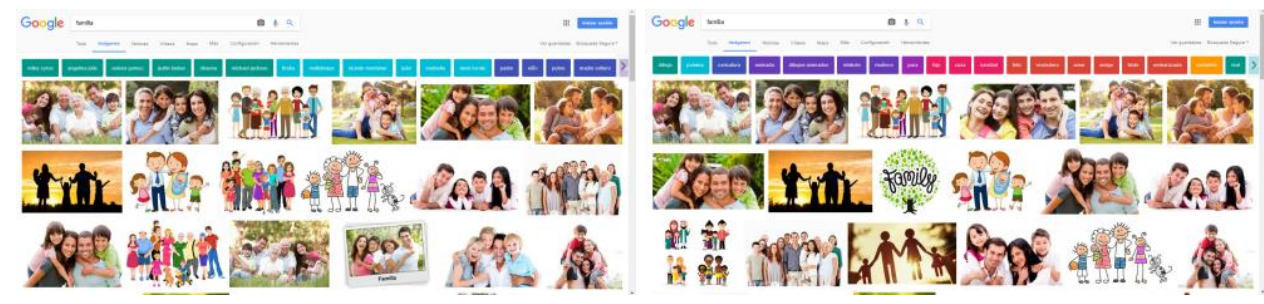

Fig. 318 primeros resultados de la palabra familia en el buscador de imágenes de google el 21 y el 30 de septiembre de 2017

La búsqueda en google de imágenes con la palabra familia nos devuelve una realidad muy simple y estereotipada. Lo que vemos en el $75 \%$ de las imágenes son fotografías de una mujer, un hombre, un niño y una niña abrazados y sonrientes delante de un fondo verde, que reconocemos como progenitores y descendientes. En algunas aparecen también una pareja, hombre y mujer más mayores, que reconoceremos como abuelos, padres e hijos. Todos blancos, occidentales y en entornos naturales. La felicidad también irradia en los dibujos (un 25\%) en estos primeros 18 resultados.

Los discursos de la fotografía artística se descubren entonces como heterodoxias absolutamente necesarias que proponen miradas alternativas. El extrañamiento adolescente en el trabajo de Sally Man, la crudeza de la dependencia social en Richard Billingham, el documento vivo y crudo en las imágenes a sus amigos y a ella 
De la red a la mesa. Una metodología docente para pensar con imágenes. - From the net to the table. A teaching methodology to think with images.

misma con Nan Goldin, las rupturas y desencuentros con Sophie Calle, la pose familiar en el trabajo de Tina Barney, la soledad de los padres de Larry Sultan, la puesta en escena de la gran familia de Mira Bernabeu, la búsqueda de relatos familiares de Virginia Espa... solo unos pocos ejemplos que sirvan al alumnado a descubrir algunas otras formas de contar quienes somos con nuestra familia.

\subsection{Experiencia}

El Taller de Imagen 2.0. parte de un primer acercamiento a la metodología y el tema. Primero trabajando sobre el texto de Tartas y Guridi «Cartografías de la memoria. Aby Warburg y el Atlas Mnemosyne» se comprende cuáles son las premisas para generar un atlas. Justo después se revisa la obra de los artistas que han trabajado sobre el tema de la familia "y el silencio".

Los alumnos pueden entonces generar un atlas propio a partir de una imagen que previamente han traído de casa sobre el tema y que será a partir de la cual podrán ir sumando otras al montaje de su atlas; para configurar un collage-montaje de esas imágenes y otras muchas, normalmente hablando sobre su propia familia y sus silencios.

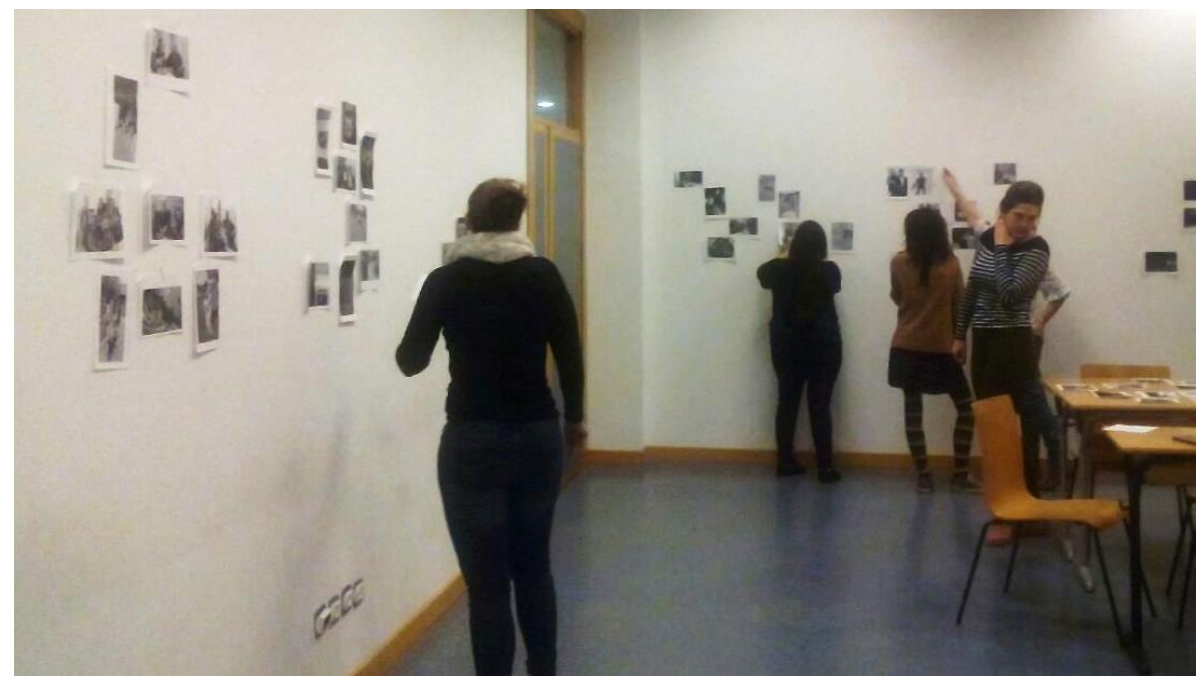

Fig. 4 Trabajando con los atlas personales sobre el tema de la familia y el silencio en el Master de Periodismo Cultural en marzo de 2017

El planteamiento inicial invitaba al alumnado a escoger imágenes de la red para generar un contenido metafórico, es decir no literal o propio. Esta primera experiencia nos enseñó que el alumnado tiene ya muchas imágenes propias y de sus familias en las redes sociales y salvo una alumna, el resto decidió colocar a los suyos unos junto a otros. Su discurso también narraba y describía las relaciones familiares entre ellos constituyendo más un álbum familiar que un atlas personal sobre la familia y el silencio en la mayoría de los casos. Hubo dos alumnas que sin embargo consiguieron acercarse a la temática de manera menos literal. Una de ellas configuró un espacio de confrontación sobre un doloroso desencuentro familiar con imágenes de las redes sociales propias. Otra consiguió que las imágenes funcionaran de forma metafórica sobre su propia realidad y ampliaran así las sinergias entre las distintas fotos y sus múltiples significados. Las imágenes empáticas resolvían relaciones íntimas y profundas asociadas directamente al tema propuesto y su experiencia.

Al día siguiente después de profundizar en el tema y la metodología con algunas referencias más, los alumnosas reconfiguran un panel común sobre la familia y el silencio que aporte sus distintas experiencias y miradas, y dónde la sinergias, encuentros y vectores de relación tienen que ser ahora consensuados. 


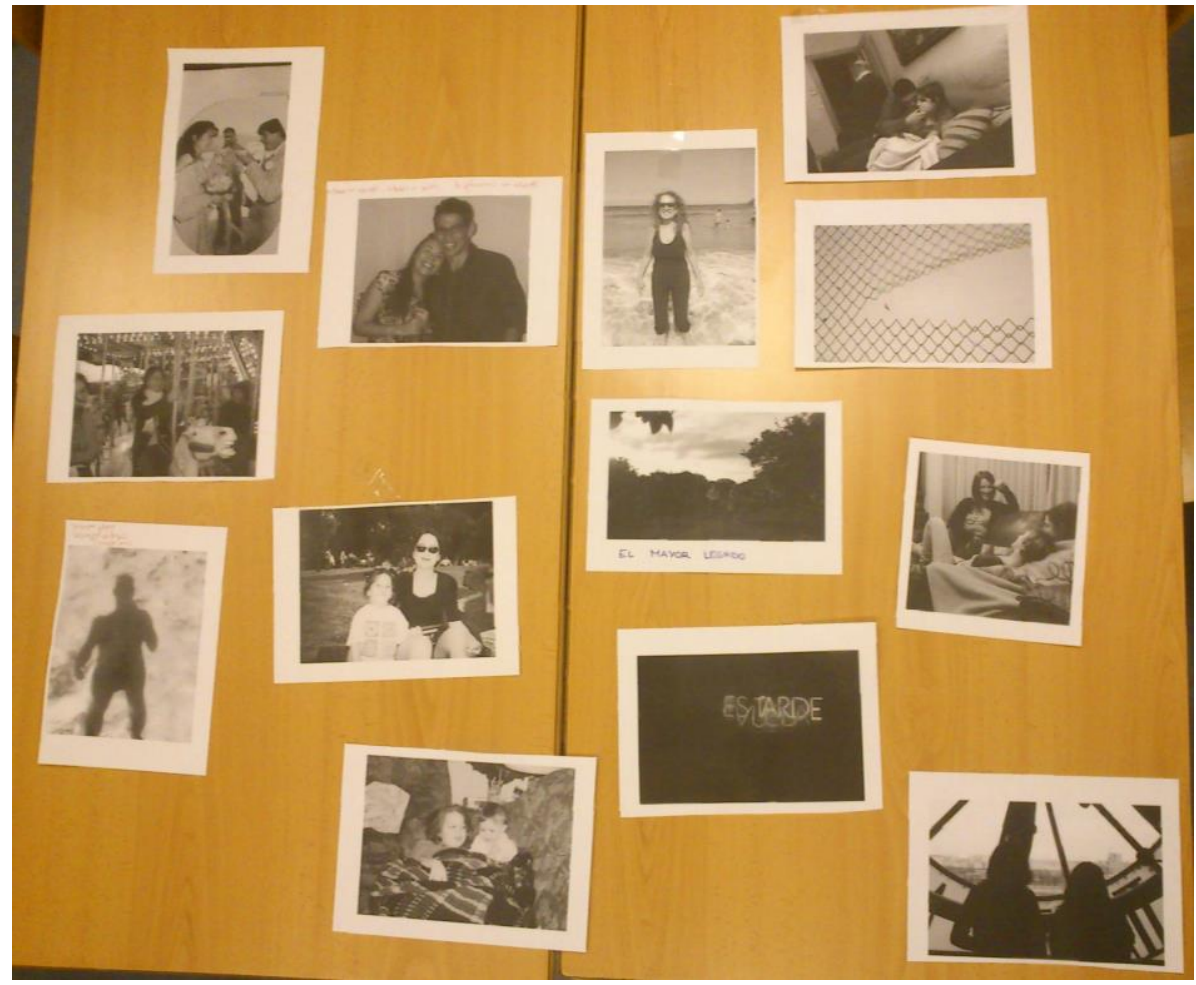

Fig. 5 Propuesta de atlas común sobre la familia y el silencio en el Master de Periodismo Cultural en marzo de 2017

Este panel común convoca preguntas y respuestas a través del Atlas. Estas preguntas pretenden esbozar algunas respuestas, no tanto como propuestas terminadas, si no como planteamientos a partir de los cuales volver a mirar, combinar, recolocar... como si de todos los puntos posibles infinitos a través de los que observar una realidad se planteara uno nuevo que puede otra vez transformarse y plantearse.

- ¿Creéis que existe en la red una representación generalizada de la forma naturalizada de identidad familiar?

- ¿Qué es una narrativa familiar canónica?, ¿Qué representa habitualmente y qué no?

- ¿Ha cambiado algo con la introducción de los archivos familiares contemporáneos: blogs, instagram, Facebook...?

- ¿En qué se diferencian las representaciones canónicas y las artísticas-familiares?

- ¿Es posible, en la fotografía familiar, separar los sujetos que representan de los sujetos representados?

La experiencia constata la enorme dificultad de escapar a las narrativas asentadas y construidas previamente cuando el alumnado construye sus atlas personales, y la dificultad de trazar líneas y vectores invisibles con imágenes que no nos son propias sin la utilización de la palabra o el relato.

Aun así la experiencia que supone un esfuerzo y una implicación enorme por parte del alumnado siembra una práctica dónde jugar con la autonomía, la profusión y la singularidad, al mismo tiempo que descubre una actividad psíquica de asociación, memoria y juego de la infancia y la imaginación... para descubrirnos a nosotros mismos implicados en la búsqueda de las imágenes que nos cuenten y nos construyan. Es decir propone un acercamiento a un lenguaje todavía por sentir profundamente y dominar.

\section{Conclusiones}

En 1984, en un magnífico texto titulado 'De los espacios otros' Foucault precisa más aun lo que entiende por 'heterotopías:' espacios de crisis y desvío, ordenamientos concretos de lugares incompatibles y tiempos 
De la red a la mesa. Una metodología docente para pensar con imágenes. - From the net to the table. A teaching methodology to think with images.

heterogéneos, dispositivos socialmente aislados pero fácilmente 'penetrables' $\mathrm{y}$, por último, máquinas concretas de imaginación que 'crean un espacio de ilusión que denuncia como más ilusorio aún todo el espacio real, todos los emplazamientos en cuyo interior está compartimentada la vida humana'. En esta perspectiva de descompartimentación -y pese a que en 1966 Foucault se niega todavía a efectuar una clara distinción entre 'mesa' y 'cuadro'-, ¿no será el atlas ese campo operatorio capaz de poner en práctica a nivel epistémico, estético, incluso político, 'una especie de impugnación a la vez mítica y real del espacio en que vivimos', o sea, el espacio para 'la mayor reserva de imaginación’. (Didi-Huberman 2011: 51-52)

El atlas surge como una poderosa herramienta de pensamiento con la que abarcar la implosión cuantitativa de imágenes que nos rodea. Sabemos que el algoritmo de Google funciona como un único punto de vista, funciona, sí, pero da una visión simple y estereotipada del mundo. Además esta metodología propicia procesos de trabajo abiertos dónde son las personas y los contenedores de imágenes las que proponen los nuevos discursos, planteamientos y encuentros, haciendo visibles estructuras alternativas y generadoras de sentido a través de imágenes.

Todavía nos queda sin embargo liberarnos de las herramientas de la palabra y la razón asentadas en lo profundo de nuestras acciones y reacciones, de nuestras formas de movernos, y así, poder colocar las imágenes libremente y conseguir generar las estructuras que las den sentido, y los vectores que revelen los sentidos de sus relaciones.

Es por lo tanto imprescindible la propuesta, el Taller de Imagen 2.0. da ahora sus primeros pasos pero en su determinación y balbuceos está el poder de movilización de nuestras estructuras y de nuestras propias imágenes. 


\section{Referencias}

ÁLBUM DE HUESCA 2016. Programa Visiona. Diputación provincial de Huesca. http://albumdehuesca.es

CARDIEL A. http://palabraeimagen.com

CRUZ MATA, F. TROYANO JIMENEZ, J.A. ENRIQUEZ DE SALAMANCA ROS, F y ORTEGA F.J. (2006) « TextRank como motor de aprendizaje en tareas de etiquetado ». Procesamiento del lenguaje natural, ISSN 1135-5948, N. 37, págs. $33-42$

DIDI-HUBERMAN, G. Atlas, ¿Cómo llevar el mundo a cuestas? Museo Nacional Centro de Arte Reina Sofia 2011

DOMINGUEZ, C. Fundación Cerezales Antonino y Cinia - FCAYC http://www.territorioarchivo.org

FONTCUBERTA, J. (2010) La cámara de Pandora. La fotografía después de la fotografía. Gustavo Gili

FONTCUBERTA, J. (2016) La furia de las imágenes. Notas sobre la postfotografía. Galaxia Gutemberg

FRANCOIS FOGEL, J. y PATIÑO, B.(2005) La Prensa sin Gutenberg. Punto de Lectura

GARRO-LARRAÑAGA, O. (2013) «Las narrativas familiares del arte contemporáneo ». Creatividad y arte. Dialógica de una lectura interpretativa del arte. Número 20

GOOGLE, Api Vision De Cloud https://cloud.google.com/vision/

GOPEGUI, B. (2017) Quédate este día y esta noche conmigo. Penguin Random House Grupo Editorial España

MARTIN PRADA, J., Prácticas artísticas e Internet en la época de las redes sociales, AKAL, 2a edición, Madrid, 2015

SANTAMARIA, M. (2017) Cultura17: Arte post Internet - Radio 3 Cultura 17 en el Museo del Prado 19/04/17 http://www.rtve.es/radio/20170419/cultura17-arte-post-internet/1526403.shtml

TARTAS RUIZ, C. GURIDI GARCI, R (2013) «Cartografias de la memoria. Aby Warburg y el Atlas Mnemosyne » EGA Expresión Gráfica Arquitectónica $N^{\circ} 21$

VV.AA. « Aby Warburg ¿Cómo llevar el mundo a cuestas? » Revista de Pensamiento y Debate del Museo Nacional Centro de Arte Reina Sofía \# 2 Primavera - Verano 2011

WARBURG, A. Atlas Mnemosyne. Akal 2010

WILLIAMS, V. « Mundos fantasmas: fotografía y familia » Revista Exit: imagen y cultura, ISSN 1577-2721, Nº 20, 2005 